\section{Stem Cell Factor}

H. Baum

Institut für Laboratoriumsmedizin, Mikrobiologie und Blutdepot, Regionale Kliniken Holding RKH GmbH, Ludwigsburg, Deutschland

Synonym(e) mast cell growth factor; KIT-Ligand; SCF; steel factor

Englischer Begriff stem cell factor

Definition Hämatologischer Wachstumsfaktor der primär auf unreife Vorläuferzellen wirkt.

Beschreibung Der humane SCF ist ein Protein, das durch alternatives Splicing in 2 Isoformen, einer löslichen Isoform bestehend aus 164 Aminosäuren und einer 157 Aminosäuren großen transmembranen Isoform, nachweisbar ist. Durch Bindung an den c-KIT Rezeptor, eine Typ-III-Tyrosinkinase, die auf hämatopoetischen Vorläuferzellen, aber auch Mastzellen sowie anderen Geweben exprimiert wird, werden intrazellulär verschiedene Signaltransduktionswege aktiviert. In der Hämatopoese ist der SCF wichtig als Wachstums- und Überlebensfaktor der Stamm- und Progenitorzellen. Zudem reguliert er die Mastzelldifferenzierung, die Ausreifung der Prä-B-Zelle, des frühen Thymozyten und der NK-Zellen.

\section{Literatur}

Smith MA, Pallister CJ, Smith JG (2001) Stem cell factor: biology and relevance to clinical practice. Acta Haematol 105:143-150 